\title{
O trabalho infantil: com a palavra as crianças e adolescentes
}

\author{
Wesley Assis de Belém¹; Maristela Vicente de Paula²; Neila Maria \\ Mendes Borges 3 ; Maisa Pires Pacheco ${ }^{4}$
}

\section{Resumo}

Segundo o Plano Nacional de Prevenção e Erradicação do Trabalho Infantil e Proteção do Adolescente Trabalhador, define-se por trabalho infantil, atividades econômicas ou mesmo de sobrevivência, remuneradas ou não, que gerem ou não lucro, desempenhadas por crianças ou adolescentes em idade inferior a dezesseis anos, com exceção a condição de aprendiz, que pode ser exercida a partir dos quatorze anos. O Trabalho Infantil, ainda é uma mazela a ser combatida veementemente no Brasil, pois, o que se almeja, é a sua erradicação, que como direito ferido, incide diretamente sobre outros direitos fundamentais, como o acesso à educação, a brincadeira/lazer e segurança, deixando as crianças e adolescentes expostos aos mais diversos tipos de situações desfavoráveis ao seu desenvolvimento, com a antecipação de compromissos da vida adulta, a exploração do trabalho com baixa remuneração e informalidade, condições insalubres de trabalho e outros. $\mathrm{O}$ presente estudo busca analisar, quais as concepções de trabalho e sua relação com o brincar que se apresentam entre as crianças e adolescentes

Especialista em Direitos Humanos da Criança e Adolescente pela Universidade Federal de Goiás/ Regional Catalão. E-mail: wesley-pdr123@hotmail.com Catalão/Goiás/Brasil.

2

Mestre. Professora no curso de Especialização em Direitos Humanos da Criança e do Adolescente - Escola que Protege/ UFG/Regional Catalão. E-mail: maristela.vicente.paula@gmail.com Catalão/Goiás/Brasil.

3

Mestre. Professora no curso de Especialização em Direitos Humanos da Criança e do Adolescente - Escola que Protege. E-mail: neilamariamendes@gmail.com Catalão/Goiás/Brasil. 4

Graduada em Letras e Artes Visuais. Especializanda em Planejamento, Implementação e Gestão. UFF. E-mail: pachecoricioli@gmail.com Catalão/Goiás/Brasil. 
participantes de um projeto de intervenção de iniciativa da sociedade civil organizada na cidade de Catalão/GO. Para tanto, o objetivo geral dessa pesquisa foi refletir sobre as concepções de trabalho e suas relações com o brincar na formação das crianças e adolescentes participantes do projeto. E, especificamente: a) abordar o trabalho infantil como um problema social brasileiro que vem sendo enfrentado, e b) analisar as concepções de trabalho e suas implicações com o brincar, presente entre as crianças e adolescentes. Como metodologia, caracteriza-se como uma pesquisa de campo com caráter exploratório e descritivo. Para a coleta de dados, foi realizada uma entrevista semi-estruturada com quatro crianças e dois adolescentes frequentadores do projeto. Os resultados da pesquisa mostram que, apesar dos avanços na legislação brasileira no que tange aos direitos da criança e adolescente e as políticas públicas que dela desdobram, bem como, o significativo aumento dos meios de comunicação de massa, temos ainda presente com forte expressão, o discurso do trabalho como referência na formação de "pessoa de bem", apartado da reflexão em torno dos direitos das crianças e adolescentes que são violados nesse processo. Assim, concluise que, são necessárias políticas mais intensas na construção de uma cultura apropriada para atender a demanda do ser criança e adolescente, implicando em mudanças no campo das concepções da própria população sobre a formação humana e social, que qualifique para a reivindicação de direitos fundamentais. Identificamos ainda, que os investimentos públicos para o combate do Trabalho Infantil ainda são insuficientes, principalmente no que se aplica ao trabalho doméstico infantil. A idéia que o trabalho forma pessoas sérias, respeitosas e honestas precisa ser questionado e reelaborado diante das implicações a que são expostas as crianças e adolescentes no trabalho infantil, mantendo um modelo explorador próprio dos princípios mais arcaico do modelo econômico vigente. A garantia do direito de formação plena da criança e do adolescente, passa pela apropriação da concepção do trabalho como emancipador e como tal, há de se garantir a formação que o antecede e o permeia.

Palavras Chave: trabalho infantil; criança e adolescente; direitos humanos. 